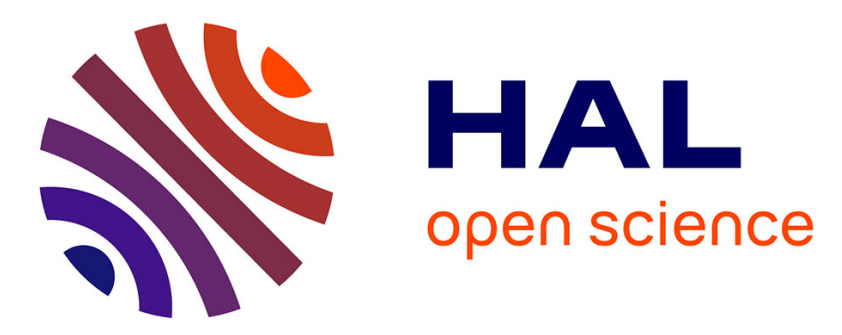

\title{
Phytolith-rich biochar increases cotton biomass and silicon-mineralomass in a highly weathered soil
}

\author{
Zimin Li, Bruno Li, Johan Yans, Nicolas Dufour, David Houben,
} Jean-Thomas Cornélis

\section{- To cite this version:}

Zimin Li, Bruno Li, Johan Yans, Nicolas Dufour, David Houben, et al.. Phytolith-rich biochar increases cotton biomass and silicon-mineralomass in a highly weathered soil. Journal of Plant Nutrition and Soil Science, 2018, 181 (4), pp.537-546. 10.1002/jpln.201800031 . hal-02176368

\section{HAL Id: hal-02176368 \\ https://hal.science/hal-02176368}

Submitted on 8 Jul 2019

HAL is a multi-disciplinary open access archive for the deposit and dissemination of scientific research documents, whether they are published or not. The documents may come from teaching and research institutions in France or abroad, or from public or private research centers.
L'archive ouverte pluridisciplinaire $\mathbf{H A L}$, est destinée au dépôt et à la diffusion de documents scientifiques de niveau recherche, publiés ou non, émanant des établissements d'enseignement et de recherche français ou étrangers, des laboratoires publics ou privés. 


\section{Phytolith-rich biochar increases cotton biomass and silicon-mineralomass in a highly 2 weathered soil}

$3{\text { Zimin } \mathrm{Li}^{1 *} \text {, Bruno Delvaux }}^{1}$, Johan Yans $^{2}$, Nicolas Dufour ${ }^{1}$, David Houben ${ }^{3}$, Jean-Thomas Cornelis ${ }^{4}$

$4 \quad{ }^{1}$ Université catholique de Louvain, Earth and Life Institute, soil science, 1348 Louvain-la-Neuve, Belgium

$5 \quad{ }^{2}$ Department of Geology, NaGRIDD, University of Namur, 5000 Namur, Belgium

$6 \quad{ }^{3}$ HydrISE, Institut Polytechnique LaSalle Beauvais, rue Pierre Waguet 19, 60026 Beauvais Cedex, France

$7 \quad{ }^{4}$ BIOSE department, Gembloux Agro-Bio Tech, University of Liege, 5030 Gembloux, Belgium

$8 \quad$ Corresponding author: zimin.li@uclouvain.be (Zimin LI)

9 Address: Université catholique de Louvain, Earth and Life Institute, soil science, 1348 Louvain-la-Neuve, 10 Belgium, Croix du Sud 2/L7.05.10,1348 Louvain-la-Neuve, Belgium

11 Resubmitted to the journal of Journal of Plant Nutrition and Soil Science (jpln.201700236)

12 Tables: $\mathbf{4}$

13 Figures: 4

14 Pages: $\mathbf{2 4}$ 


\section{Abstract}

16 Non-essential silicon $(\mathrm{Si})$ is beneficial to plants. It increases the biomass of Si-accumulator plants by 17 improving photosynthetic activity and alleviating stresses. Desilication, however, takes place because of 18 natural soil weathering and removal of harvested biomass. Pyrolysis transforms Si-rich biomass into 19 biochar that can be used to supply bioavailable Si.

20 Here, we applied two biochar materials differing in Si content on soils differing in weathering stage: a 21 young Cambisol and a highly weathered Nitisol. We studied the impact of biochar supply on the 22 bioavailability of $\mathrm{Si}$, cotton biomass and $\mathrm{Si}$ mineralomass. The biochar materials derived from, 23 respectively: Miscanthus $x$ giganteus $-\mathrm{Mi}-\left(34.6 \mathrm{~g} \mathrm{Si} \mathrm{kg}^{-1}\right.$ in biochar) and soft woody material -SW- (0.9 $24 \mathrm{~g} \mathrm{Si} \mathrm{kg}^{-1}$ in biochar). They were compared to conventional Si fertilizer wollastonite $-\mathrm{Wo}-\left(\mathrm{CaSiO}_{3}\right)$. 25 Amendments were incorporated in soils at the rate of $3 \%(\mathrm{w} / \mathrm{w})$. The content of bioavailable Si in soil was 26 determined through $0.01 \mathrm{M} \mathrm{CaCl}_{2}$ extraction.

27 In the Cambisol, the proportion $\left[\mathrm{CaCl}_{2}\right.$ extractable $\mathrm{Si}$ : total $\mathrm{Si}$ content] was significantly smaller for Mi $28(0.9 \%)$ than for Wo (5.2\%). In the Nitisol, this proportion was much larger for Mi (1.4\%) than for Wo 29 (0.7\%). Mi-biochar significantly increased Si-mineralomass relatively to SW-biochar in both soils. This 30 increase was, however, much larger in the Nitisol (5.9-fold) than in the Cambisol (2.2-fold).

31 Mi biochar is thus an alternative Si fertilizer to Wo to supply bioavailable Si, increase plant biomass, and 32 promote the biological cycle of Si in the soil-plant system in the Nitisol. Besides, it increased soil fertility 33 and soil organic carbon content.

34 Keywords biochar, bioavailable silicon, soil desilication, cotton 


\section{Introduction}

Silicon ( $\mathrm{Si}$ ) is ubiquitous in rocks and soils. Si is not essential, but beneficial to plants. It increases photosynthetic activity and plant resistance against various biotic and abiotic stresses (Belanger, 1995; Fauteux et al., 2005; Liang et al., 2007). Aqueous monosilicic acid $\left(\mathrm{H}_{4} \mathrm{SiO}_{4}{ }^{0}\right)$ is ubiquitous in soil solution where plant roots take it up. In plants, mass flow transports $\mathrm{H}_{4} \mathrm{SiO}_{4}{ }^{0}$ upwards to transpiration sites. Therein, water loss increases $\mathrm{H}_{4} \mathrm{SiO}_{4}{ }^{0}$ concentration, and induces polymerization through Si-O-Si bounds, and further precipitation of hydrated amorphous silica as phytoliths (amorphous $\mathrm{SiO}_{2} \bullet \mathrm{nH}_{2} \mathrm{O}$ ) (Epstein, 1994; $M a$ et al., 2006). Phytoliths (PhSi) are major biogenic silicate minerals (BSi). They return into the topsoil with dead plant materials, and further contribute to the pool of dissolved $\mathrm{Si}$ (DSi) in soil (Keller et al., 2012) because of their solubility (Fraysse et al., 2009). They thus supply the pool of bioavailable Si in soils under forests (Cornelis et al., 2011; Gérard et al., 2008), grasslands (Alexandre et al., 2011; Blecker et al., 2006; Issaharou-Matchi et al., 2016; White et al., 2012) and croplands either in temperate conditions (Vandevenne et al., 2015) or in the humid tropics (Henriet et al., 2008). The contribution of PhSi to DSi pool can be substantially impacted by land use (Barão et al., 2014; Struyf et al., 2010), harvest exportation (Keller et al., 2012; Vandevenne et al., 2015; Vandevenne et al., 2012), soil weathering stage (Henriet et al., 2008) and, overall, soil processes (Cornelis and Delvaux, 2016).

The regular removal of straws of high-Si accumulator plants combined with natural desilication in freely drained soils leads to a substantial decrease of PhSi and DSi pools in agroecosystems (Keller et al., 2012; Struyf et al., 2010; Vandevenne et al., 2015). Si supply may therefore be required to sustain continuous cropping in highly desilicated soils depleted in weatherable silicate minerals. The use of traditional amendments raises cost and environmental problems (Berthelsen et al., 2001; Haynes, 2014; Haynes et al., 2013; Datnoff and Heckman, 2014), prompting us to develop other ways to improve the use of available biomass.

Biochar is a black carbon used as a soil amendment. It is produced by heating organic matter under 
oxygen-limited conditions. Pyrolysis converts organic substances into stable C compounds, hence preserves atmospheric C (Lehmann and Joseph, 2015; Lehmann et al., 2011). Applied to soil, biochar retains and supplies plant nutrients (Glaser et al., 2002; Laird et al., 2010; Lehmann et al., 2003), increases soil C stock (Lehmann and Joseph, 2015), soil pH and plant growth (Biederman and Harpole, 2013). Black carbon significantly increases soil cation exchange capacity (CEC) through its large surface charge density and surface area (Liang et al., 2006). Yet the effect of biochar on plant growth largely depends on soil properties and biochar types (Biederman and Harpole, 2013; Crane-Droesch et al., 2013; Jeffery et al., 2011).

Pyrolysis of plant residues concentrates PhSi minerals (Houben et al., 2014) which in turn contribute to supply DSi (Houben et al., 2014; Xiao et al., 2014), and increase Si uptake by plants (Liu et al., 2014). The impact of both the PhSi content of biochar and soil silicon availability on plant growth and Si uptake is, however, unknown. Here, we used two biochars differing in Si content, and apply them on soils differing in weathering stage, respectively, a young Cambisol and an old, highly weathered, Nitisol. We studied the release of DSi after biochar application. We further investigated the effect of biochar on soil fertility, plant biomass and $\mathrm{Si}$ mineralomass, and compared it to the one of $\mathrm{CaSiO}_{3}$-wollastonite.

\section{Materials and methods}

\section{Biochar, wollastonite and soils}

Biochars and wollastonite. The biochars were produced by industrial pyrolysis $\left(550^{\circ} \mathrm{C}\right.$, heating rate $65^{\circ} \mathrm{C} / \mathrm{min}$, kiln residence time $12 \mathrm{~min}$ ) at UK Biochar Research Centre (UKBRC), respectively from Miscanthus (Miscanthus x giganteus)-Mi- and soft wood (Mixed softwood pellets) -SW- (Table 1). The wollastonite -Wo- was provided by R.T Vanderbilt Company, Inc. (Norwalk, CT, USA) (Table 1). In the following text, the biochars and wollastonite are considered as soil amendments.

Soils and soil:amendment mixtures. The two soils key out as, respectively, a Dystric Cambisol (CA) and a 
83 Rhodic Nitisol (NI) in the WRB system (IUSS, 2014). CA (Forest of Lauzelle, Louvain-la Neuve, 84 Belgium) developed from quaternary calcareous silty loess under humid temperate conditions (Titeux and Delvaux, 2009). NI is a paleosol from the quarry of Transinne (Belgium), formed under humid tropical paleo-conditions. The quarry exhibits a deep $65 \mathrm{~m}$ saprolithic profile derived from Early Devonian bedrock, containing kaolinite, resistant muscovite and quartz, and Fe oxyhydroxides (Thiry et al., 2006). The soil samples were air-dried and sieved at 2-mm. The soil:amendment mixtures were made at 100:3 g:g (dry soil weight), and are named CA-Mi, CA-SW, CA-Wo, NI-Mi, NI-SW and NI-Wo.

$\mathrm{CaCl}_{2}$ extraction of $\mathrm{Si}$

91 The extraction was carried out on the Si amendments, soils and soil:amendment mixtures before the cotton 92 pot experiment. The $\mathrm{CaCl}_{2}$-extractable $\mathrm{Si}$ content $\left(\mathrm{CaCl}_{2}-\mathrm{Si}\right)$ was determined using a $5 \mathrm{~g}: 50 \mathrm{ml}(0.01 \mathrm{M}$ $93 \mathrm{CaCl}_{2}$ ) soil:solution ratio, and a $5 \mathrm{~h}$ continuous shaking time (Haysom and Chapman, 1975). After 94 centrifuged at $3,000 \times \mathrm{g}$ for $20 \mathrm{~min}$, the supernatant was separated for analysis. The residues were 95 submitted to five successive extractions during 5 days. The concentration of $\mathrm{Si}$ was measured in each 96 extract by Inductively Coupled Plasma-Atomic Emission Spectrometry (ICP-AES).

97 Analyses. $\mathrm{pH}$ was measured in, respectively, $\mathrm{H}_{2} \mathrm{O}$ and $\mathrm{KCl} 1 \mathrm{M}$, with $5 \mathrm{~g}: 25 \mathrm{ml}$ suspensions. The CEC and 98 content of exchangeable cations were determined using $\mathrm{CH}_{3} \mathrm{COONH}_{4} 1 \mathrm{M}$ buffered at $\mathrm{pH}=7$ (Chapman, 99 1965). Elemental analysis was carried out after calcination and Li-metaborate + Li-tetraborate fusion 100 (Chao and Sanzolone, 1992). The elemental contents were determined by ICP-AES. Elemental contents of 101 alkaline and alkaline-earth cations were summed up as the total reserve in bases (TRB), which estimates 102 the content of weatherable minerals (Herbillon, 1986). Total carbon (C) and nitrogen (N) contents were 103 measured by dry combustion with a CNS analyzer (Flash EA1112 Series).

104 Scanning Electron Microscopy (SEM). The analyses of biochar particles were performed on specimens 105 using a JEOL FEG SEM 7600F, equipped with Energy Dispersive X-ray Spectrometry system (EDX, Jeol 
106 JSM2300 with a resolution $<129 \mathrm{eV}$ ) operating at $15 \mathrm{keV}$ with a working distance of $8 \mathrm{~mm}$ for the

107 element detection. The acquisition time for the chemical spectra lasted $100 \mathrm{~s}$ with a probe current of $1 \mathrm{nA}$.

\section{$108 \quad$ Plant material and analyses, pot experiment}

109 Cotton plant. We used Gossypium hirsutum, var (STAM 59A-Bollgard II) from southern Burkina Faso.

110 Pot experiment in a phytotron (5 months). The soil:amendment mixtures (100:3 g:g) were irrigated with

111 deionized water and allowed to equilibrate for a week at $70 \%$ of field water holding capacity before

112 planting. After germination in deionized water, the plantlets were allowed to grow up to 5-cm. They were

113 then transplanted into pots $(7.5 \mathrm{~L})$ containing the respective soil:amendment mixtures (3kg dry weight), in

114 triplicate under $28^{\circ} \mathrm{C}$ and relative humidity at $80 \%$. Each pot was watered every three days with $33 \mathrm{ml}$

115 deionized water during the first two months, and $100 \mathrm{ml}$ the last three months. No nutrients were supplied.

116 We collected the aboveground plant part after 5 months for further drying at $55^{\circ} \mathrm{C}$ during 7 days prior to

117 biomass weighing.

118 Analyses. Mineral analysis was carried out after calcination at $450^{\circ} \mathrm{C}$ for 1 day and fusion in Li119 metaborate + Li-tetraborate at $1,000^{\circ} \mathrm{C}$ (Chao and Sanzolone, 1992), followed by ash dissolution with 120 concentrated $\mathrm{HNO}_{3}$. Element contents were measured by ICP-AES. Element mineralomass was computed 121 from total element contents and cotton biomass.

\section{Statistical analyses}

123 We used the SPSS 17.0 statistical software to carry out the one-way analysis of variance (ANOVA) (at $124 p<0.05$ level) and LSD (at $p<0.05$ level).

\section{Results}


127 As shown in Table 1, the OC content (\%) was 84.9 in SW, 77.1 in Mi and 0.6 in Wo. The total N content 128 (\%) was 1.2 in $\mathrm{SW}$ and 2.0 in Mi. The contents of $\mathrm{CaCl}_{2}$ extractable $\mathrm{Si}\left(\mathrm{g} \mathrm{kg}^{-1}\right)$ were larger in Mi (11.4) 129 than in Wo (8.8) and SW (0.01). Si content of Wo amounted to $233.3 \mathrm{~g} \mathrm{~kg}^{-1}$ which was 7 times larger than 130 that of $\mathrm{Mi}\left(34.6 \mathrm{~g} \mathrm{~kg}^{-1}\right)$, and 259 times larger than in $\mathrm{SW}\left(0.9 \mathrm{~g} \mathrm{~kg}^{-1}\right)$. The contents of $\mathrm{Ca}, \mathrm{Mg}$ in Wo were 131 also significantly larger than in Mi and WS. The contents of $\mathrm{K}\left(\mathrm{cmol}_{\mathrm{c}} \mathrm{kg}^{-1}\right)$ were larger in Mi (14.9) than 132 in SW (2.6) and Wo (1.1). Figure 1 illustrated the SEM micrographs and associated EDX spectra of 133 biochar materials SW and Mi. In particular, Fig. 1(f) showed the occurrence of dumbbell-shaped, fine silt134 sized phytoliths in Mi biochar. As inferred from Fig.1 (e), they were abundant and undamaged after 135 pyrolysis at $550{ }^{\circ} \mathrm{C}$.

\section{Soil and soil:amendment properties}

$\mathrm{CA}$ and NI are acid soils since their $\mathrm{pH}_{\text {water }}$ values were 4.6 and 5.2, respectively (Table 2). C and N contents, CEC and contents of exchangeable cations were larger in CA than in NI. Of course, biochar application resulted in a huge increase in $\mathrm{C}$ content while Wo did not. The latter application led to a marked increase in $\mathrm{pH}$ and content of exchangeable Ca. SW application did not generate any change of $\mathrm{pH}, \mathrm{CEC}$, contents of exchangeable cations and base saturation whatever the soil type. To the contrary, Mi application induced a significant increase of these parameters. In particular, exchangeable $\mathrm{K}$ content $143\left(\mathrm{cmol}_{\mathrm{c}} \mathrm{kg}^{-1}\right)$ increased from, respectively 0.2 to 0.97 in CA, and $0.05 \mathrm{t} 0.81$ in NI. From Total contents of $\mathrm{Al}$ and $\mathrm{Fe}\left(\mathrm{g} \mathrm{kg}^{-1}\right)$ amounted to, respectively, 39.2 and 18.5 in CA, 96.5 and 30.6 in NI (Table 3). Total Si content $\left(\mathrm{g} \mathrm{kg}^{-1}\right)$ in CA and NI was 376.8 and 311.9 , respectively. Computed values of $\mathrm{Si} /(\mathrm{Al}+\mathrm{Fe})$ atomic 146 ratio were thus larger in CA (7.5) than in NI (2.7). TRB $\left(\mathrm{cmol}_{\mathrm{c}} \mathrm{kg}^{-1}\right)$ amounted to 112 in CA and 99 in NI.

147 Residual weatherable minerals in CA were plagioclase and feldspar, and soil clay minerals. From Figure 2, 148 CA clay minerals consisted of kaolinite and an assemblage of 2:1:1 and 2:1 clay minerals involving 149 chlorite, illite, vermiculite and smectite. NI distinctly differed by the large dominance of well crystallized 150 muscovite and kaolinite. In the Nitisol, $\mathrm{K}$ was by far the largest dominant cation in TRB, in line with the 151 occurrence of muscovite, a dioctahedral mica resistant to weathering. The large amount of non- 
152 exchangeable K (Table 3) thus hided the advanced weathering stage of NI because muscovite is stable and 153 does not weather in soils. The reserve of weatherable minerals was then estimated by the difference 154 between TRB and the content of non-exchangeable K, excluding K-bearing muscovite. [TRB-K] (cmol ${ }_{\mathrm{c}}$ $155 \mathrm{~kg}^{-1}$ ) amounted to 72.5 in CA and 22.1 in NI, indicating the strongly advanced weathering stage of NI. 156 [TRB-K] did not increase following biochar application. To the contrary, wollastonite application 157 generated a marked increase of total Ca content $\left(\mathrm{cmol}_{\mathrm{c}} \mathrm{kg}^{-1}\right)$ : from 15 to 63 in CA, and from 1 to 48 in NI. 158 Cumulative $\mathrm{CaCl}_{2}$ - $\mathrm{Si}\left(\mathrm{mg} \mathrm{kg}^{-1}\right.$ ) (Table 3, Figure 3) was significantly larger in CA (34) than in NI (24). $159 \mathrm{CaCl}_{2}$-Si significantly $(p<0.01)$ increased after Wo application in CA (398.7) and NI (71.7). Unlike SW, 160 Mi significantly $(p<0.01)$ increased $\mathrm{CaCl}_{2}-\mathrm{Si}$ in CA (43.2) and $\mathrm{NI}(38.5)$.

\section{Biomass and mineralomass of cotton plants}

162 The cotton biomass $\left(\mathrm{g}\right.$ plant $\left.^{-1}\right)$ was significantly larger in CA (8.6) than in NI (0.32) (Table 4). Mi 163 significantly increased cotton biomass, by $84 \%$ in CA, and $368 \%$ in NI. Mi significantly increased plant 164 mineralomass of $\mathrm{Ca}, \mathrm{K}$ and $\mathrm{Mg}$ in both soils. Plant Si mineralomass (mg plant ${ }^{-1}$ ) was, by far, significantly 165 larger in CA (10.6) than in NI (0.8). Relatively to SW, Mi significantly increased the plant Si content (g Si $166 \mathrm{~kg}^{-1} \mathrm{DW}$ ): 0.65 for CA-Mi and 0.74 for NI-Mi, as well as plant Si mineralomass (mg Si plant $\mathrm{H}^{-1}$ ): 10.52 for 167 CA-Mi and 1.12 for NI-Mi). Si mineralomass indeed increased by $120 \%$ in CA-Mi and $180 \%$ in NI-Mi 168 relatively to the untreated soils $\mathrm{CA}$ and $\mathrm{Mi}$.

\section{Discussion}

\section{Weathering stage of soils}

171 The values of $\mathrm{TRB}$ and $\mathrm{Si} /(\mathrm{Al}+\mathrm{Fe})$ ratio as well as the nature of secondary clay minerals are used to 172 assess soil weathering stage (Herbillon, 1986). Taking into account the stability of muscovite in soils, NI 173 exhibited an advanced weathering stage characteristic of strongly weathered ferrallitic soils (Herbillon, 174 1986). In CA, the large dominance of quartz is characteristic of soils of the Belgian loess belt, in which the 
175 reserve of weatherable minerals is concentrated in the clay fraction (Brahy et al., 2000). CA soil clay 176 minerals (kaolinite, chlorite, illite, vermiculite and smectite: Figure 2a) revealed a mineralogical 177 assemblage typical of moderately weathered soils under temperate climates. To the contrary, NI soil clay 178 minerals (Figure 2b) make an assemblage typical for desilicated, highly weathered soils formed under 179 humid tropical conditions. Consequently, $\mathrm{CaCl}_{2}-\mathrm{Si}$ content was significantly larger in $\mathrm{CA}$ than in NI 180 (Figure 3).

182 As it is linked to the DSi pool from which plant roots take up $\mathrm{Si}, \mathrm{CaCl}_{2}-\mathrm{Si}$ could quantify the pool of 183 bioavailable $\mathrm{Si}$ in soils (Sauer et al., 2006). Cumulative $\mathrm{CaCl}_{2}-\mathrm{Si}\left(\mathrm{mg} \mathrm{kg}^{-1}\right)$ was significantly larger in 184 soil:Wo (398.7 in CA-Wo, 71.7 in NI-Wo) than in soil:biochar CA-Mi (43.2), NI-Mi (38.5), CA-SW 185 (30.9) and NI-SW (24.1) (Table 3; Figure 3). Wo is indeed an efficient Si fertilizer releasing bioavailable 186 Si. For each amendment, $\mathrm{CaCl}_{2}-\mathrm{Si}$ was systematically smaller in NI:amendment mixtures. Part of $\mathrm{H}_{4} \mathrm{SiO}_{4}{ }^{\circ}$ 187 released by amendments was undoubtedly adsorbed by oxide surfaces in NI as it commonly occurs in 188 highly weathered soils (Herbillon et al., 1977).

189 To further assess Si mobility, we define the efficiency of each amendment (AM) using $\mathrm{CaCl}_{2}-\mathrm{Si}$ and total 190 Si contents (Table 3) as follows:

$$
\frac{[\mathrm{CaCl} 2-\mathrm{Si} \text { in soil: } \mathrm{AM}]-[\mathrm{CaCl} 2-\mathrm{Si} \text { in soil }]}{\text { Total Si content of AM }} \times 100
$$

191 In CA, the efficiency of MI was significantly smaller (0.9\%) than that of Wo (5.2\%). To the contrary, in 192 NI, Mi efficiency was larger (1.4\%) than to the one of Wo (0.7\%). Possibly phytolith solubility could be 193 larger in NI-Mi, because of a larger pH. Besides, the release of bioavailable Si was significantly larger for 194 Mi than for SW (Figure $3 \mathrm{c}$, d). The ample reserve of PhSi in Mi vs SW (34.6 vs $0.9 \mathrm{~g} \mathrm{Si} \mathrm{kg}^{-1}$, Table 1) and 195 the accessibility of phytoliths in Mi (Figure $1 \mathrm{e}, \mathrm{f}$ ) support that phytoliths readily contribute to DSi. They 
196 resist to pyrolytic temperatures as high as $550^{\circ} \mathrm{C}$, and further dissolve to release DSi given their solubility

197 (Fraysse et al., 2009). Since their dissolution rate increases with increasing $\mathrm{pH}$ in the range of $\mathrm{pH}$ 3-12

198 (Fraysse et al., 2006), the ability of phytolith-rich Mi to supply DSi is enhanced by pH increase, especially

199 in NI, where silica sorption increased $\mathrm{pH}$ of surrounding solution. Indeed, Fe oxides adsorb $\mathrm{Si}$ in soils

200 (Jones and Handreck, 1963, 1967) and control DSi (McKeague and Cline, 1963).

201 The release of bioavailable Si in Mi-amended soils was not affected by soil type and weathering stage.

202 The biochar derived from high-Si accumulator Miscanthus is thus an alternative Si fertilizer to 203 wollastonite to supply bioavailable Si in the highly weathered Nitisol.

\section{Effect of biochar amendment on soil properties}

205 As already reported (Sohi et al., 2010; Van Zwieten et al., 2010), biochar application to soils affects their 206 properties (Table 2). The impact depends, however, on the types of biochar and soil. Supplying ash 207 biochar induces a change of $\mathrm{pH}$ and nutrient availability, (Clarholm, 1994; Mahmood et al., 2003). Here, 208 applying biochar did not significantly modify CEC in CA. However, it slightly increased CEC in NI, but 209 only after Mi application, which also increased the contents of exchangeable cations, namely $\mathrm{K}$ and $\mathrm{Mg}$ in 210 CA-Mi, and $\mathrm{Ca}, \mathrm{K}, \mathrm{Na}$ and $\mathrm{Mg}$ in NI-Mi (Table 2). Such increases were not observed after SW addition.

211 Since applying Mi increased the effective CEC (ECEC), we hypothesize that it is due to an increase of 212 surface area and surface charge density of biochar particle, as previously reported for black C (Liang et al., 213 2006). The pH rise, in turn, undoubtedly led to increase ECEC (Glaser et al., 2002; Houben et al., 2014; 214 Laird et al., 2010). Relatively to SW, Mi contained more ashes and initial exchangeable and non215 exchangeable cations (Table 1 and Figure 1). Mi thus had a larger ability to increase pH and ECEC, as 216 observed by Houben et al. (2014). Furthermore, the improvement of soil properties was more pronounced 217 in NI-Mi than in CA-Mi. Base saturation (BS \%) significantly increased in both CA-Mi and NI-Mi, 218 reflecting the ability of Mi biochar to enhance nutrient availability (Table 3) as predicted by Liang et al. 
$220 \mathrm{~K}$ ) in Mi relatively to SW (Table 1). The impact of Mi biochar on soil fertility was thus positive,

221 particularly in the highly weathered Nitisol, though at a very low level tested in non-fertilized soil.

\section{Effect of biochar amendment on cotton biomass and Si mineralomass}

223 The amounts of available nutrients (exchangeable $\mathrm{Ca}, \mathrm{K}$ and $\mathrm{Mg}$ ) and bioavailable Si were larger in $\mathrm{CA}$ 224 than in NI (Tables 2 and 3). Thus, the cotton biomass and mineralomass were significantly larger in CA 225 than in NI regardless the type of biochar amendment.

Plant response to biochar amendment varied with the type of biochar (Spokas and Reicosky, 2009) and application rate (Liu et al., 2013). Mi-biochar increased both the plant biomass and element uptake, as a result of elevated nutrient availability $(\mathrm{Ca}, \mathrm{Mg}$ and $\mathrm{K})$. Here, both the $\mathrm{Ca}, \mathrm{Mg}$ and $\mathrm{K}$ mineralomass and 229 soil $\mathrm{Ca}, \mathrm{Mg}$ and $\mathrm{K}$ contents were significantly larger, respectively, in CA-Mi and NI-Mi than in CA-SW and NI-SW (Table 2 and Table 4). Nutrients were likely released in soil via the degradation of labile organic compounds associated with biochar (Rajkovich et al., 2012; Topoliantz et al., 2005; Yamato et al., 232 2006). Moreover, biochar amendment promotes plant productivity through the increase of $\mathrm{pH}$, which in 233 turn increases nutrient availability and/or decrease mineral toxicities (Lehmann et al., 2003; Rondon et al., 234 2007; Yamato et al., 2006). Here, the biochar-induced increase of ECEC likely promoted plant growth and 235 biomass (Table 2 and Table 4) (Major et al., 2010). The marked difference of soil fertility between CA and 236 NI, discussed above, induced a huge difference in cotton biomass (g plant ${ }^{-1}$ ): 8.8 in CA vs 0.3 in NI (Table 2373 and Table 4). The increase of cotton biomass was 4.7 fold from NI to NI-Mi and 1.8-fold from CA to 238 CA-Mi, whereas no significant effect was measured after SW amendment. Mi-biochar induced an increase 239 of CEC and ECEC, and thus improved soil fertility in the highly weathered Nitisol, thereby promoting 240 plant growth.

241 Si uptake by cotton plants markedly differed between CA and NI (Figure 4). After Mi application, Si 
243 g.plant $\left.{ }^{-1}\right)$ was very low in NI (0.2-1.5) compared to CA (8.8-16.2) (Table 4). As discussed above,

244 phytoliths were abundant in Mi; they dissolved and released DSi, thereby contributing to the pool of

245 bioavailable $\mathrm{Si}$, which was readily taken up by plant roots (Figure 1, 2, 3; Table 3). This effect was

246 particularly important in the highly weathered Nitisol depleted in primary and secondary silicates.

\section{Conclusion}

248 Miscanthus biochar and wollastonite amendments significantly $(p<0.01)$ enhanced the release of $\mathrm{CaCl}_{2^{-}}$ extractable Si in a young Cambisol and an old, highly weathered Nitisol. Soft wood biochar amendment had no effect on the release of $\mathrm{CaCl}_{2}$-extractable $\mathrm{Si}$ in both soils. Miscanthus biochar supply increased

251 ECEC, particularly the content of exchangeable K, while soft wood biochar did not have any effect on 252 these parameters whatever the soil type. Both biochar amendments induced a significant effect on $\mathrm{C}$ and $\mathrm{N}$ contents in both soils. Miscanthus biochar generated a significant increase of cotton biomass. That 254 increase was, however, larger in the Nitisol than in the Cambisol, since it was 4.7-fold in the former and 255 1.8-fold in the latter. In terms of Si uptake after Mi application, the increase in the Nitisol (5.9-fold) was 256 much larger than in the Cambisol (2.2-fold), supporting a larger efficiency of Si release from Miscanthus 257 phytoliths in the Nitisol.

258 Our data thus highlight that Miscanthus biochar is an alternative Si amendment to wollastonite to supply 259 bio-available $\mathrm{Si}$, increase plant biomass and promote the biological cycle of $\mathrm{Si}$ in the soil-plant system. 260 This positive impact of a Si-rich biochar is, however, larger in the old, desilicated, highly weathered 261 Nitisol. Overall, it demonstrates that Si is progressively released from phytolith-rich biochar, and directly 262 contributes to the pool of bioavailable Si for plant root uptake in soil. This is particularly important for 263 agro-ecosystems in which high-Si accumulator plants grow in highly weathered, desilicated soils. Further 264 field experiments are required to confirm the effect of phytolith-rich biochar as a Si fertilizer over the 265 whole plant cycle. Furthermore, the efficiency of various biochar types to release Si and plant nutrients 266 should be studied. 
We thank A. Iserentant and C. Givron for laboratory assistance (UCL). Z Li is supported by the "Fonds Spécial de Recherché" of the UCL in 2014-2015 and the Aspirant (ASP)-Fonds National de la Recherché Scientifique» (FNRS) of Belgium in 2015-2019.

\section{References}

Alexandre, A. , Bouvet, M. , Abbadie, L. (2011). The role of savannas in the terrestrial Si cycle: a casestudty from Lamto, Ivory Coast. Global and Planetary Change 78, 162-169.

Barão, L. , Clymans, W. , Vandevenne, F. , Meire, P. , Conley, D., Struyf, E. (2014). Pedogenic and biogenic alkaline-extracted silicon distributions along a temperate land-use gradient. European Journal of Soil Science 65, 693-705.

Belanger, R. R. (1995). Soluble silicon: its role in crop and disease management of greenhouse crops. Plant Dis 79, 329-336.

Berthelsen, S. , Noble, A. , Garside, A. (2001). Silicon research down under: past, present, and future. Studies in Plant Science 8, 241-255.

Biederman, L. A. , Harpole, W. S. (2013). Biochar and its effects on plant productivity and nutrient cycling: a meta-analysis. GCB bioenergy $\mathbf{5}, 202-214$.

Blecker, S. W. , McCulley, R. L. , Chadwick, O. A. , Kelly, E. F. (2006). Biologic cycling of silica across a grassland bioclimosequence. Global Biogeochemical Cycles 20.

Brahy, V. , Deckers, J. , Delvaux, B. (2000). Estimation of soil weathering stage and acid neutralizing capacity in a toposequence Luvisol-Cambisol on loess under deciduous forest in Belgium. European Journal of Soil Science 51, 1-13.

Chao, T. , Sanzolone, R. (1992). Decomposition techniques. Journal of Geochemical Exploration 44, 65106.

Chapman, H. (1965). Cation-exchange capacity. Methods of soil analysis. Part 2. Chemical and microbiological properties, 891-901.

Clarholm, M. (1994). Granulated wood ash and a ' $\mathrm{N}$-free'fertilizer to a forest soil-effects on $\mathrm{P}$ availability. Forest Ecology and Management 66, 127-136.

Cornelis, J.-T. , Titeux, H. , Ranger, J. , Delvaux, B. (2011). Identification and distribution of the readily soluble silicon pool in a temperate forest soil below three distinct tree species. Plant and soil 342, 369-378.

Cornelis, J. T. , Delvaux, B. (2016). Soil processes drive the biological silicon feedback loop. Functional Ecology 30, 1298-1310.

Crane-Droesch, A. , Abiven, S. , Jeffery, S., Torn, M. S. (2013). Heterogeneous global crop yield response to biochar: a meta-regression analysis. Environmental Research Letters 8, 044049.

Datnoff, L. E. , Heckman, J. R. (2014). Silicon fertilizers for plant disease protection. In "World Fertilizer Congress", Vol. 16, pp. 36.

Epstein, E. (1994). The anomaly of silicon in plant biology. Proceedings of the National Academy of Sciences 91, 11-17.

Fauteux, F. , Rémus-Borel, W. , Menzies, J. G. , Bélanger, R. R. (2005). Silicon and plant disease resistance against pathogenic fungi. FEMS Microbiology letters 249, 1-6.

Fraysse, F. , Pokrovsky, O. S., Schott, J. , Meunier, J.-D. (2006). Surface properties, solubility and dissolution kinetics of bamboo phytoliths. Geochimica et Cosmochimica Acta 70, 1939-1951.

Fraysse, F. , Pokrovsky, O. S., Schott, J. , Meunier, J.-D. (2009). Surface chemistry and reactivity of plant 
phytoliths in aqueous solutions. Chemical Geology 258, 197-206.

Gérard, F. , Mayer, K., Hodson, M., Ranger, J. (2008). Modelling the biogeochemical cycle of silicon in soils: application to a temperate forest ecosystem. Geochimica et Cosmochimica Acta 72, 741758 .

Glaser, B. , Lehmann, J. , Zech, W. (2002). Ameliorating physical and chemical properties of highly weathered soils in the tropics with charcoal-a review. Biology and fertility of soils 35, 219-230.

Haynes, R. J. (2014). A contemporary overview of silicon availability in agricultural soils. Journal of Plant Nutrition and Soil Science 177, 831-844.

Haynes, R. J. , Belyaeva, O. , Kingston, G. (2013). Evaluation of industrial wastes as sources of fertilizer silicon using chemical extractions and plant uptake. Journal of Plant Nutrition and Soil Science 176, 238-248.

Haysom, M. , Chapman, L. (1975). Some aspects of the calcium silicate trials at Mackay. In "Proceedings".

Henriet, C., Bodarwé, L. , Dorel, M. , Draye, X., Delvaux, B. (2008). Leaf silicon content in banana (Musa spp.) reveals the weathering stage of volcanic ash soils in Guadeloupe. Plant and Soil 313, 71-82.

Herbillon, A. (1986). Chemical estimation of weatherable minerals present in the diagnostic horizons of low activity clay soils. In "Proceedings of the 8th International Clay Classification Workshop: Classification, Characterization and Utilization of Oxisols (part 1)[Beinroth, FH, Camargo, MN and Eswaran (ed.)][39-48](Rio de Janeiro, 1986)".

Herbillon A., Gallez A., Juo S.R. (1977) Characteristics of Silica Sorption and Solubility as Parameters to Evaluate the Surface Properties of Tropical Soils: II. The Index of Silica Saturation. Soil Science Society of America Journal 41, 1151-1154.

Houben, D. , Sonnet, P. , Cornelis, J.-T. (2014). Biochar from Miscanthus: a potential silicon fertilizer. Plant and soil 374, 871-882.

Issaharou-Matchi, I. , Barboni, D. , Meunier, J.-D. , Saadou, M. , Dussouillez, P. , Contoux, C. , ZirihiGuede, N. (2016). Intraspecific biogenic silica variations in the grass species Pennisetum pedicellatum along an evapotranspiration gradient in South Niger. Flora-Morphology, Distribution, Functional Ecology of Plants 220, 84-93.

IUSS (2014). World reference base for soil resources 2014 international soil classification system for naming soils and creating legends for soil maps. FAO, Rome.

Jeffery, S. , Verheijen, F. G. , Van Der Velde, M. , Bastos, A. C. (2011). A quantitative review of the effects of biochar application to soils on crop productivity using meta-analysis. Agriculture, ecosystems \& environment 144, 175-187.

Jones, L., Handreck, K. (1963). Effects of iron and aluminium oxides on silica in solution in soils.

Jones, L. , Handreck, K. (1967). Silica in soils, plants, and animals. Advances in agronomy 19, 107-149.

Keller, C. , Guntzer, F. , Barboni, D. , Labreuche, J. , Meunier, J.-D. (2012). Impact of agriculture on the Si biogeochemical cycle: input from phytolith studies. Comptes Rendus Geoscience 344, 739-746.

Kloss, S. , Zehetner, F. , Wimmer, B. , Buecker, J. , Rempt, F., Soja, G. (2014). Biochar application to temperate soils: effects on soil fertility and crop growth under greenhouse conditions. Journal of plant nutrition and soil science 177, 3-15.

Laird, D. A., Fleming, P., Davis, D. D., Horton, R., Wang, B., Karlen, D. L. (2010). Impact of biochar amendments on the quality of a typical Midwestern agricultural soil. Geoderma 158, 443-449.

Lehmann, J. , da Silva Jr, J. P. , Steiner, C., Nehls, T. , Zech, W. , Glaser, B. (2003). Nutrient availability and leaching in an archaeological Anthrosol and a Ferralsol of the Central Amazon basin: fertilizer, manure and charcoal amendments. Plant and soil 249, 343-357.

Lehmann, J. , Joseph, S. (2015). "Biochar for environmental management: science, technology and implementation," Routledge.

Lehmann, J. , Rillig, M. C. , Thies, J. , Masiello, C. A. , Hockaday, W. C. , Crowley, D. (2011). Biochar effects on soil biota-a review. Soil Biology and Biochemistry 43, 1812-1836.

Liang, B. , Lehmann, J. , Solomon, D. , Kinyangi, J. , Grossman, J. , O'neill, B. , Skjemstad, J. , Thies, J. , Luizao, F. , Petersen, J. (2006). Black carbon increases cation exchange capacity in soils. Soil 
Liang, Y. , Sun, W. , Zhu, Y.-G. , Christie, P. (2007). Mechanisms of silicon-mediated alleviation of abiotic stresses in higher plants: a review. Environmental pollution 147, 422-428.

Liu, X. , Li, L., Bian, R. , Chen, D. , Qu, J. , Wanjiru Kibue, G. , Pan, G. , Zhang, X. , Zheng, J. , Zheng, J. (2014). Effect of biochar amendment on soil-silicon availability and rice uptake. Journal of plant nutrition and soil science 177, 91-96.

Liu, X. , Zhang, A. , Ji, C., Joseph, S. , Bian, R. , Li, L. , Pan, G. , Paz-Ferreiro, J. (2013). Biochar's effect on crop productivity and the dependence on experimental conditions - a meta-analysis of literature data. Plant and soil 373, 583-594.

Ma, J. F. , Tamai, K. , Yamaji, N. , Mitani, N. , Konishi, S. , Katsuhara, M. , Ishiguro, M. , Murata, Y. , Yano, M. (2006). A silicon transporter in rice. Nature 440, 688-691.

Mahmood, S. , Finlay, R. D. , Fransson, A.-M. , Wallander, H. (2003). Effects of hardened wood ash on microbial activity, plant growth and nutrient uptake by ectomycorrhizal spruce seedlings. FEMS Microbiology Ecology 43, 121-131.

Major, J. , Rondon, M. , Molina, D. , Riha, S. J. , Lehmann, J. (2010). Maize yield and nutrition during 4 years after biochar application to a Colombian savanna oxisol. Plant and soil 333, 117-128.

McKeague, J. , Cline, M. (1963). Silica in soil solutions: II. The adsorption of monosilicic acid by soil and by other substances. Canadian Journal of Soil Science 43, 83-96.

Rajkovich, S. , Enders, A. , Hanley, K. , Hyland, C. , Zimmerman, A. R. , Lehmann, J. (2012). Corn growth and nitrogen nutrition after additions of biochars with varying properties to a temperate soil. Biology and Fertility of Soils 48, 271-284.

Rondon, M. A. , Lehmann, J. , Ramírez, J. , Hurtado, M. (2007). Biological nitrogen fixation by common beans (Phaseolus vulgaris L.) increases with bio-char additions. Biology and fertility of soils $\mathbf{4 3}$, 699-708.

Sauer, D., Saccone, L. , Conley, D. J. , Herrmann, L. , Sommer, M. (2006). Review of methodologies for extracting plant-available and amorphous $\mathrm{Si}$ from soils and aquatic sediments. Biogeochemistry 80, 89-108.

Sohi, S. , Krull, E. , Lopez-Capel, E., Bol, R. (2010). A review of biochar and its use and function in soil. Advances in agronomy 105, 47-82.

Spokas, K. , Reicosky, D. (2009). Impacts of Sixteen Different Biochars on Soil Greenhouse Gas Production. Annals of Environmental Science 3, 179-193.

Struyf, E. , Smis, A. , Van Damme, S. , Garnier, J. , Govers, G. , Van Wesemael, B. , Conley, D. J. , Batelaan, O. , Frot, E. , Clymans, W. (2010). Historical land use change has lowered terrestrial silica mobilization. Nature communications 1, 129.

Thiry, M. ,Quesnel, F., Yans, J., Wyns, R. , Vergari, A. , Theveniaut, H. , Simon-Coinçon, R. , Ricordel, C. , Moreau, M.-G. , Giot, D. (2006). Continental France and Belgium during the early Cretaceous: paleoweatherings and paleolandforms. Bulletin de la Société géologique de France 177, 155-175.

Titeux, H. , Delvaux, B. (2009). Experimental study of DOC, nutrients and metals release from forest floors developed under beech (Fagus sylvatica L.) on a Cambisol and a Podzol. Geoderma 148, 291-298.

Topoliantz, S. , Ponge, J.-F. , Ballof, S. (2005). Manioc peel and charcoal: a potential organic amendment for sustainable soil fertility in the tropics. Biology and Fertility of Soils 41, 15-21.

Van Zwieten, L. , Kimber, S. , Morris, S. , Chan, K. , Downie, A. , Rust, J. , Joseph, S. , Cowie, A. (2010). Effects of biochar from slow pyrolysis of papermill waste on agronomic performance and soil fertility. Plant and soil 327, 235-246.

Vandevenne, F. , Barão, L. , Ronchi, B. , Govers, G. , Meire, P. , Kelly, E. , Struyf, E. (2015). Silicon pools in human impacted soils of temperate zones. Global Biogeochemical Cycles 29, 1439-1450.

Vandevenne, F. , Struyf, E. , Clymans, W. , Meire, P. (2012). Agricultural silica harvest: have humans created a new loop in the global silica cycle? Frontiers in Ecology and the Environment 10, 243248 . 
White, A. F. ,Vivit, D. V. , Schulz, M. S., Bullen, T. D. , Evett, R. R. , Aagarwal, J. (2012). Biogenic and pedogenic controls on $\mathrm{Si}$ distributions and cycling in grasslands of the Santa Cruz soil chronosequence, California. Geochimica et Cosmochimica Acta 94, 72-94.

Xiao, X. , Chen, B ., Zhu, L. (2014). Transformation, morphology, and dissolution of silicon and carbon in rice straw-derived biochars under different pyrolytic temperatures. Environmental science \& technology 48, 3411-3419.

Yamato, M. , Okimori, Y. , Wibowo, I. F. , Anshori, S. , Ogawa, M. (2006). Effects of the application of charred bark of Acacia mangium on the yield of maize, cowpea and peanut, and soil chemical properties in South Sumatra, Indonesia. Soil science and plant nutrition 52, 489-495. 
422 Table1. Selected properties of the soft wood (SW), Miscanthus (Mi) biochars and wollastonite (Wo): $\mathrm{pH}_{\text {water }}$, total contents of Carbon (C), Nitrogen $(\mathrm{N}), \mathrm{CaCl}_{2}$ extractable $\mathrm{Si}\left(\mathrm{CaCl}_{2}-\mathrm{Si}\right)$, major alkaline and alkaline-earth cations $(\mathrm{Ca}, \mathrm{Mg}, \mathrm{K}, \mathrm{Na})$, and silicon $(\mathrm{Si})$.

\begin{tabular}{|c|c|c|c|c|c|c|c|c|c|}
\hline \multirow{2}{*}{$\begin{array}{l}\text { 8Amendments } \\
9\end{array}$} & $\mathrm{pH}$ & ${ }^{\S} \mathrm{C}$ & ${ }^{\S} \mathrm{N}$ & $\mathrm{CaCl}_{2}-\mathrm{Si}$ & $\mathrm{Ca}$ & $\mathrm{Mg}$ & $\mathrm{Na}$ & $\mathrm{K}$ & $\mathrm{Si}$ \\
\hline & $\mathrm{H}_{2} \mathrm{O}$ & \multicolumn{2}{|c|}{$(\%)$} & $\mathrm{g} \mathrm{kg}^{-1}$ & \multicolumn{5}{|c|}{$\left(\mathrm{g} \mathrm{kg}^{-1}\right)$} \\
\hline 180W & 7.4 & 84.90 & 1.15 & $0.01(0.00)$ & $2.79(0.79)$ & $0.53(0.17)$ & $0.15(0.05)$ & $2.20(0.61)$ & $0.77(0.22)$ \\
\hline$M i$ & 10.1 & 77.13 & 2.01 & $11.45(1.05)$ & $6.92(0.10)$ & $2.15(0.10)$ & $0.58(0.03)$ & $14.87(0.16)$ & $34.65(0.23)$ \\
\hline Wo & 9.1 & 0.56 & nd & $8.87(1.04)$ & $314.71(2.54)$ & $10.80(0.06)$ & $<0.01$ & $1.10(0.06)$ & $233.34(2.03)$ \\
\hline
\end{tabular}

425 Note: nd means not determined; § : Single measurements only. 


\begin{tabular}{|c|c|c|c|c|c|c|c|c|c|c|}
\hline \multirow[t]{2}{*}{ Treatments } & \multicolumn{2}{|c|}{$\mathrm{pH}$} & \multicolumn{2}{|l|}{$\mathrm{C}$} & \multirow[t]{2}{*}{$\mathrm{CEC}$} & \multicolumn{4}{|c|}{$\begin{array}{l}\text { Exchangeable cations } \\
\left(\mathrm{cmol}_{\mathrm{c}} \mathrm{kg}^{-1}\right)\end{array}$} & \multirow{2}{*}{$\begin{array}{l}\text { BS } \\
(\%)\end{array}$} \\
\hline & $\mathrm{H}_{2} \mathrm{O}$ & $\mathrm{KCl}$ & - & & & $\mathrm{Ca}^{2+}$ & $\mathrm{K}^{+}$ & $\mathrm{Na}^{+}$ & $\mathrm{Mg}^{2+}$ & \\
\hline $\mathrm{CA}$ & $4.62(0.02) \mathrm{c}$ & $3.72(0.03) \mathrm{c}$ & $14.12(1.32) b$ & $1.19(0.05) \mathrm{a}$ & $6.67(0.31) b$ & $2.31(0.05) b$ & $0.20(0.02) b$ & $0.04(0.02) \mathrm{c}$ & $0.39(0.01) \mathrm{c}$ & 44.08 \\
\hline CA-SW & $4.72(0.00) \mathrm{c}$ & $3.73(0.01) \mathrm{c}$ & $30.95(2.38) a$ & $1.22(0.12) \mathrm{a}$ & $6.14(0.82) \mathrm{b}$ & $2.29(0$ & $0.22(0.02) b$ & $0.04(0.01) \mathrm{c}$ & 1)c & 47.88 \\
\hline CA-Mi & $5.03(0.03) \mathrm{b}$ & $4.08(0.02) \mathrm{b}$ & $35.85(2.56) a$ & $1.27(0.35) \mathrm{a}$ & $5.98(0.17) b$ & $2.36(0.06) b$ & $0.97(0.20) \mathrm{a}$ & $0.07(0.01) b$ & 0.47 & 64.72 \\
\hline CA-Wo & $6.25(0.01) \mathrm{a}$ & $5.36(0.02) \mathrm{a}$ & $14.78(1.23) \mathrm{b}$ & $1.11(0.03) \mathrm{a}$ & $8.11(0.11) \mathrm{a}$ & $5.42(0.13) \mathrm{a}$ & $0.24(0.03) \mathrm{b}$ & $0.10(0.01) \mathrm{a}$ & $0.43(0.00) \mathrm{b}$ & 76.32 \\
\hline $\mathrm{NI}$ & $5.18(0.04) \mathrm{z}$ & $4.32(0.01) \mathrm{z}$ & & $0.27(0.02) \mathrm{y}$ & $0.68(0.08) \mathrm{z}$ & $0.15(0.01) \mathrm{z}$ & $0.05(0.02) \mathrm{y}$ & $0.01(0.01) \mathrm{z}$ & $0.30(0.00) \mathrm{y}$ & 75.00 \\
\hline NI-SW & $5.45(0.00) \mathrm{z}$ & $4.44(0.06) \mathrm{z}$ & $26.41(4.56) x$ & $0.53(0.12) \mathrm{x}$ & $0.87(0.13) \mathrm{z}$ & $0.16(0.02) \mathrm{z}$ & $0.07(0.04) y$ & $0.02(0.00) \mathrm{z}$ & $0.30(0.00) y$ & 63.22 \\
\hline NI-Mi & $6.25(0.10) \mathrm{y}$ & $5.79(0.13) y$ & $21.29(3.69) \mathrm{x}$ & $0.50(0.11) x$ & $1.04(0.07) \mathrm{y}$ & $0.36(0.13) \mathrm{y}$ & $0.81(0.55) \mathrm{x}$ & $0.07(0.03) \mathrm{x}$ & $0.37(0.05) \mathrm{x}$ & 154.81 \\
\hline NI-Wo & $7.84(0.12) x$ & $6.53(0.10) x$ & $0.85(0.32) y$ & $0.27(0.01) \mathrm{y}$ & $1.82(0.03) \mathrm{x}$ & $2.89 \times(0.23)$ & $0.03(0.03) \mathrm{z}$ & $0.06(0.01) y$ & $0.28(0.02) \mathrm{z}$ & 179.12 \\
\hline
\end{tabular}

Table 2. Selected physico-chemical properties of the untreated soils (Cambisol CA, Nitisol NI) and amended soils, using soft wood (CA-SW, NI$\mathrm{SW}$, Miscanthus (CA-Mi, NI-Mi) and wollastonite (CA-Wo, NI-Wo). The average values presented with distinct letters (a, b, c) in the Cambisol and $(\mathrm{x}, \mathrm{y}, \mathrm{z})$ in the Nitisol are significantly different at the $p<0.05$ level of confidence according to LSD's multiple comparison 
435 : cumulative amount after 5 extractions (see also Figure 3);

$436{ }^{2}$ : TRB is the sum of total contents of $\mathrm{Ca}, \mathrm{Mg}, \mathrm{Na}$ and $\mathrm{K}$ in soil (Herbillon, 1986);

$437{ }^{3}$ : TRB-K is the sum of total contents of $\mathrm{Ca}, \mathrm{Mg}$ and $\mathrm{Na}$ in soil, excluding non-exchangeable $\mathrm{K}$ [total $\mathrm{K}$ - exchangeable $\mathrm{K}$ ], associated with 438 resistant muscovite or oxidized biotite, both dioctahedral micaceous minerals.

Table 3. Total contents of selected major elements and Total Reserve in Bases (TRB) in CA and NI, CA-SW, CA-Mi, CA-Wo; NI-SW, NI-Mi, NIWo). The average values presented with distinct letters $(a, b, c)$ in Cambisols and $(x, y, z)$ in Nitisols are significantly different at the $p<0.05$ level of confidence according to LSD's multiple comparison test.

\begin{tabular}{|c|c|c|c|c|c|c|c|c|c|c|c|}
\hline \multirow[t]{2}{*}{ Treatments } & \multirow{2}{*}{$\begin{array}{l}\mathrm{CaCl}_{2}-\mathrm{Si}^{1} \\
\left(\mathrm{mg} \mathrm{kg}^{-1}\right)\end{array}$} & \multirow{2}{*}{$\begin{array}{l}\text { Total Si } \\
\left(\mathrm{g} \mathrm{kg}^{-1}\right)\end{array}$} & \multicolumn{4}{|c|}{$\begin{array}{l}\text { Total elements } \\
\qquad\left(\mathrm{cmol}_{\mathrm{c}} \mathrm{kg}^{-1}\right)\end{array}$} & \multirow[t]{2}{*}{$\mathrm{TRB}^{2}$} & \multirow[t]{2}{*}{$\begin{array}{l}{[\mathrm{TRB}-} \\
\mathrm{K}]^{3}\end{array}$} & \multicolumn{2}{|c|}{$\begin{array}{l}\text { Total elements } \\
\qquad\left(\mathrm{g} \mathrm{kg}^{-1}\right)\end{array}$} & \multirow[t]{2}{*}{$\mathrm{Si} /(\mathrm{Al}+\mathrm{Fe})$} \\
\hline & & & $\mathrm{Ca}$ & $\mathrm{K}$ & $\mathrm{Na}$ & $\mathrm{Mg}$ & & & $\mathrm{Al}$ & $\mathrm{Fe}$ & \\
\hline CA-SW & $30.95(1.00) \mathrm{c}$ & 365.47 & 16.55 & 39.06 & 28.92 & 25.34) & 109.9 & 70.5 & 38.02 & 17.92 & 7.52 \\
\hline CA-Mi & $43.22(1.90) \mathrm{b}$ & 366.50 & 17.08 & 40.00 & 28.99 & 25.34 & 111.4 & 72.4 & 38.01 & 17.93 & 7.54 \\
\hline NI-SW & $24.11(1.04) \mathrm{z}$ & 302.57 & 1.46 & 75.70 & 7.47 & 13.13 & 97.7 & 22.0 & 93.62 & 29.71 & 2.69 \\
\hline NI-Mi & $38.50(1.52) y$ & 303.60 & 2.00 & 76.64 & 7.54 & 13.13 & 99.3 & 23.4 & 93.64 & 29.73 & 2.70 \\
\hline NI-Wo & $71.70(2.64) x$ & 305.84 & 48.16 & 75.57 & 7.46 & 15.64 & 146.8 & 71.3 & 93.73 & 29.72 & 2.72 \\
\hline
\end{tabular}


440

441

442

443

444

Table 4. Experimental values of cotton biomass, plant contents of $\mathrm{Ca}, \mathrm{Mg}, \mathrm{Na}, \mathrm{K}$, and $\mathrm{Si}$, and element mineralomass (i.e. uptake) in the cotton plants grown on the untreated soils (Cambisol CA, Nitisol NI), and biochar-amended soils (Miscanthus Mi; Soft Wood SW). The average values presented with distinct letters $(\mathrm{a}, \mathrm{b}, \mathrm{c})$ in $\mathrm{CA}$ and $(\mathrm{x}, \mathrm{y}, \mathrm{z})$ in NI are significantly different at the $p<0.05$ level of confidence according to LSD's multiple comparison test.

\begin{tabular}{c|rrrr|rrr}
\hline \multicolumn{2}{c}{ Treatments } & \multicolumn{1}{c}{ CA } & \multicolumn{1}{c}{ CA-SW } & \multicolumn{1}{c}{ CA-Mi } & \multicolumn{1}{c}{ NI } & NI-SW \\
\hline Biomass & g plant $^{-1}$ & $8.82(1.10) \mathrm{b}$ & $8.63(2.51) \mathrm{b}$ & $16.24(2.11) \mathrm{a}$ & $0.32(0.07) \mathrm{y}$ & $0.24(0.11) \mathrm{y}$ & $1.51(0.40) \mathrm{x}$ \\
$\mathrm{Ca}$ & & $14.64(4.59) \mathrm{a}$ & $7.79(0.62) \mathrm{b}$ & $13.22(2.05) \mathrm{a}$ & $3.16(1.09) \mathrm{y}$ & $3.82(1.39) \mathrm{y}$ & $11.42(2.46) \mathrm{x}$ \\
$\mathrm{Mg}$ & & $2.76(0.48) \mathrm{a}$ & $2.13(0.30) \mathrm{b}$ & $2.48(0.27) \mathrm{a}$ & $1.54(0.00) \mathrm{y}$ & $1.30(0.10) \mathrm{y}$ & $2.25(0.05) \mathrm{x}$ \\
$\mathrm{Na}$ & $\mathrm{g} \mathrm{kg}^{-1}$ & $0.24(0.08) \mathrm{a}$ & $0.11(0.02) \mathrm{b}$ & $0.09(0.03) \mathrm{b}$ & $0.82(0.01) \mathrm{x}$ & $0.58(0.00) \mathrm{y}$ & $0.20(0.22) \mathrm{z}$ \\
$\mathrm{K}$ & & $15.17(3.39) \mathrm{b}$ & $15.15(1.33) \mathrm{b}$ & $23.03(4.96) \mathrm{a}$ & $10.40(0.01) \mathrm{y}$ & $14.51(0.60) \mathrm{y}$ & $26.74(1.61) \mathrm{x}$ \\
$\mathrm{Si}$ & & $0.54(0.16) \mathrm{b}$ & $0.46(0.11) \mathrm{b}$ & $0.65(0.03) \mathrm{a}$ & $0.58(0.00) \mathrm{y}$ & $0.54(0.00) \mathrm{y}$ & $0.74(0.11) \mathrm{x}$ \\
$\mathrm{Ca}$ & & $129.09(25.14) \mathrm{b}$ & $67.22(16.59) \mathrm{c}$ & $214.73(37.52) \mathrm{a}$ & $1.01(0.22) \mathrm{y}$ & $0.92(0.65) \mathrm{y}$ & $17.24(4.52) \mathrm{x}$ \\
$\mathrm{Mg}$ & & $24.35(7.27) \mathrm{bc}$ & $18.42(3.05) \mathrm{c}$ & $40.25(2.64) \mathrm{a}$ & $0.49(0.11) \mathrm{y}$ & $0.31(0.16) \mathrm{y}$ & $3.41(0.89) \mathrm{x}$ \\
$\mathrm{Na}$ & mg plant $^{-1}$ & $2.09(0.84) \mathrm{a}$ & $0.92(0.32) \mathrm{c}$ & $1.53(0.44) \mathrm{b}$ & $0.26(0.05) \mathrm{xy}$ & $0.14(0.07) \mathrm{y}$ & $0.30(0.07) \mathrm{x}$ \\
$\mathrm{K}$ & & $133.76(45.57) \mathrm{b}$ & $130.78(28.06) \mathrm{b}$ & $374.05(79.87) \mathrm{a}$ & $3.33(0.72) \mathrm{y}$ & $3.48(1.73) \mathrm{y}$ & $40.38(10.59) \mathrm{x}$ \\
$\mathrm{Si}$ & & $4.76(0.32) \mathrm{b}$ & $3.93(0.21) \mathrm{c}$ & $10.52(2.30) \mathrm{a}$ & $0.19(0.05) \mathrm{y}$ & $0.13(0.07) \mathrm{y}$ & $1.12(0.12) \mathrm{x}$ \\
\hline
\end{tabular}




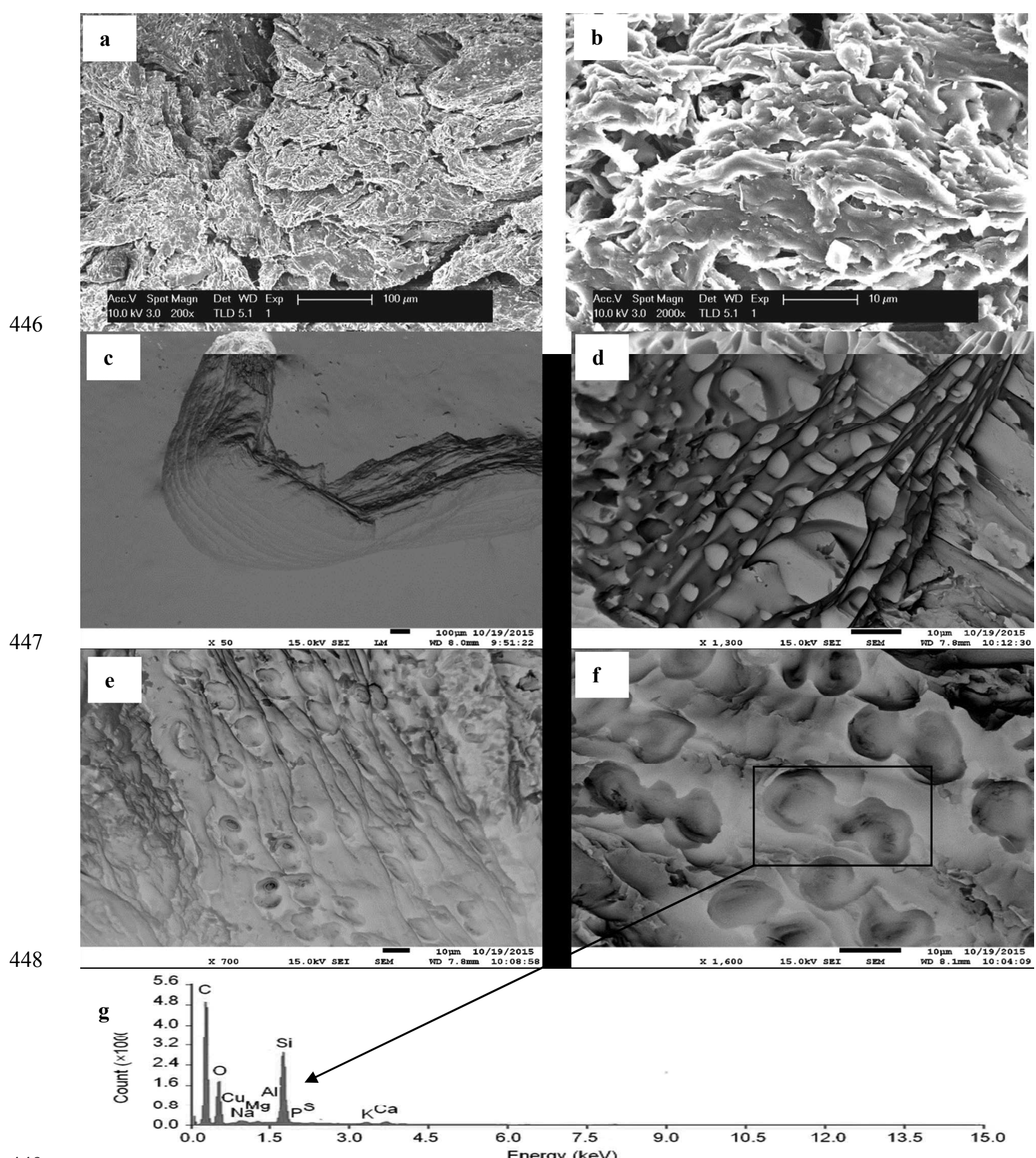

Figure 1. Scanning electron micrographs (SEM) images of biochar materials from soft wood (a, b), and 451 452 Miscanthus (Miscanthus $\times$ giganteus) straws $(\mathbf{c}, \mathbf{d})$. e and $\mathbf{f}$ are the SEM images of Miscanthus phytoliths. The energy dispersive X-ray spectra (EDX) (g) collected from f, shows the dominance of $\mathrm{C}, \mathrm{O}$ and $\mathrm{Si}$, hence documenting the presence of phytoliths $\left(\mathrm{SiO}_{2} \cdot \mathrm{nH}_{2} \mathrm{O}\right)$. 


\section{Clay fraction - Cambisol}

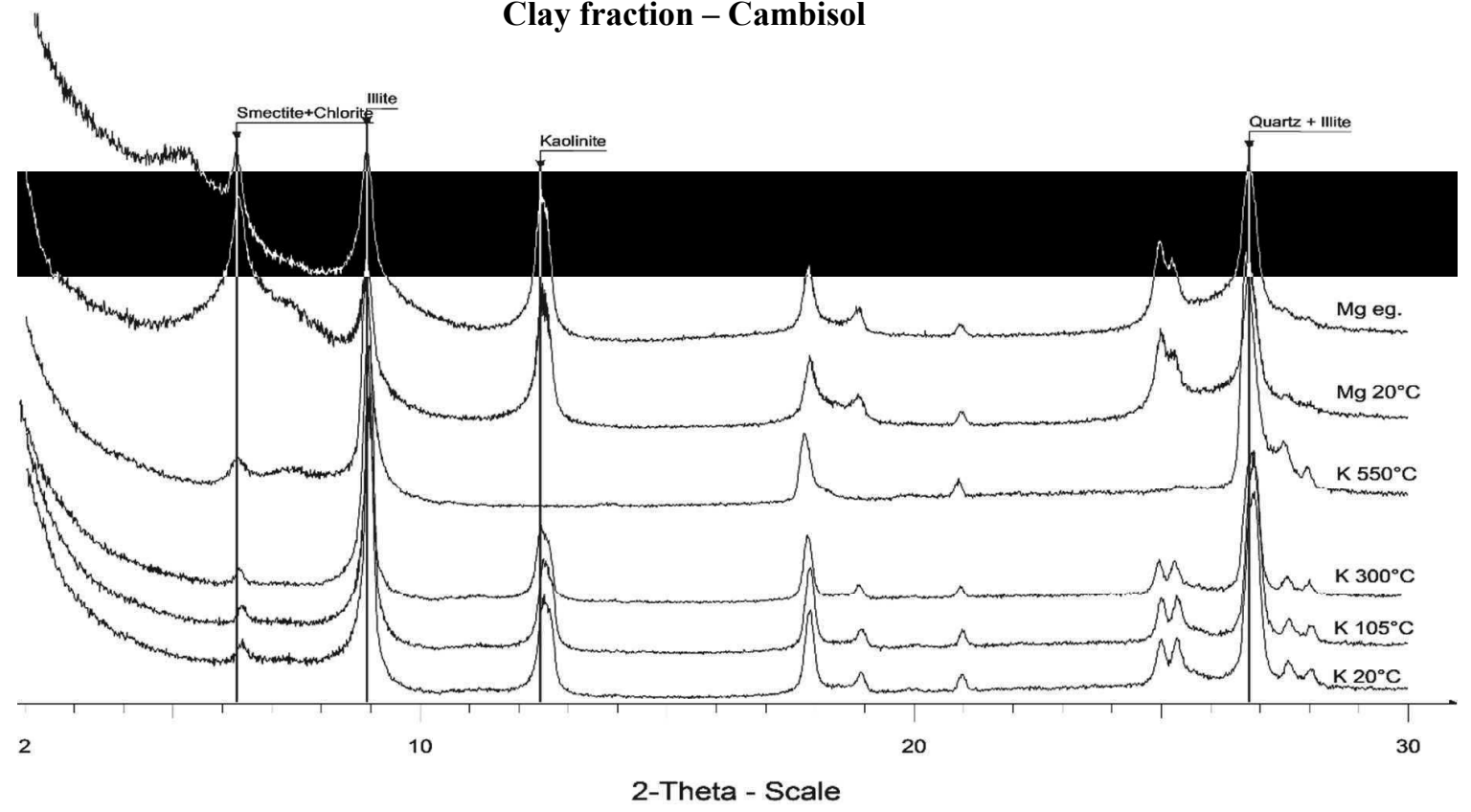

Clay fraction - Nitisol

b

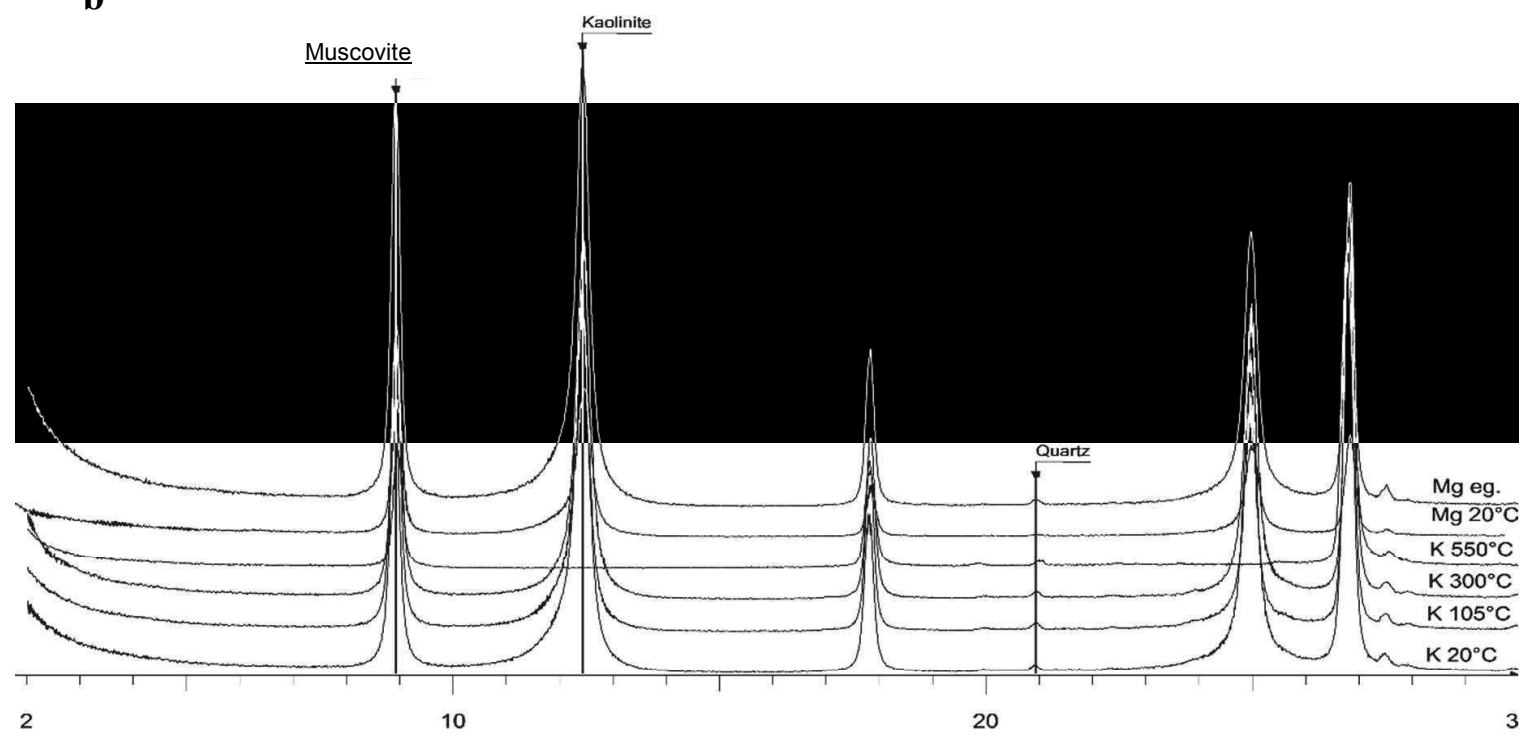

2-Theta - Scale

Figure 2. XRD patterns of the clay-size fraction $(<2 \mu \mathrm{m})$ of the Cambisol CA (a) and Nitisol NI (b) after $\mathrm{K}^{+}$-saturation at $20,105,300$ and $550^{\circ} \mathrm{C} ; \mathrm{Mg}^{2+}$-saturation at $20^{\circ} \mathrm{C}$, and saturation with ethyleneglycol. 


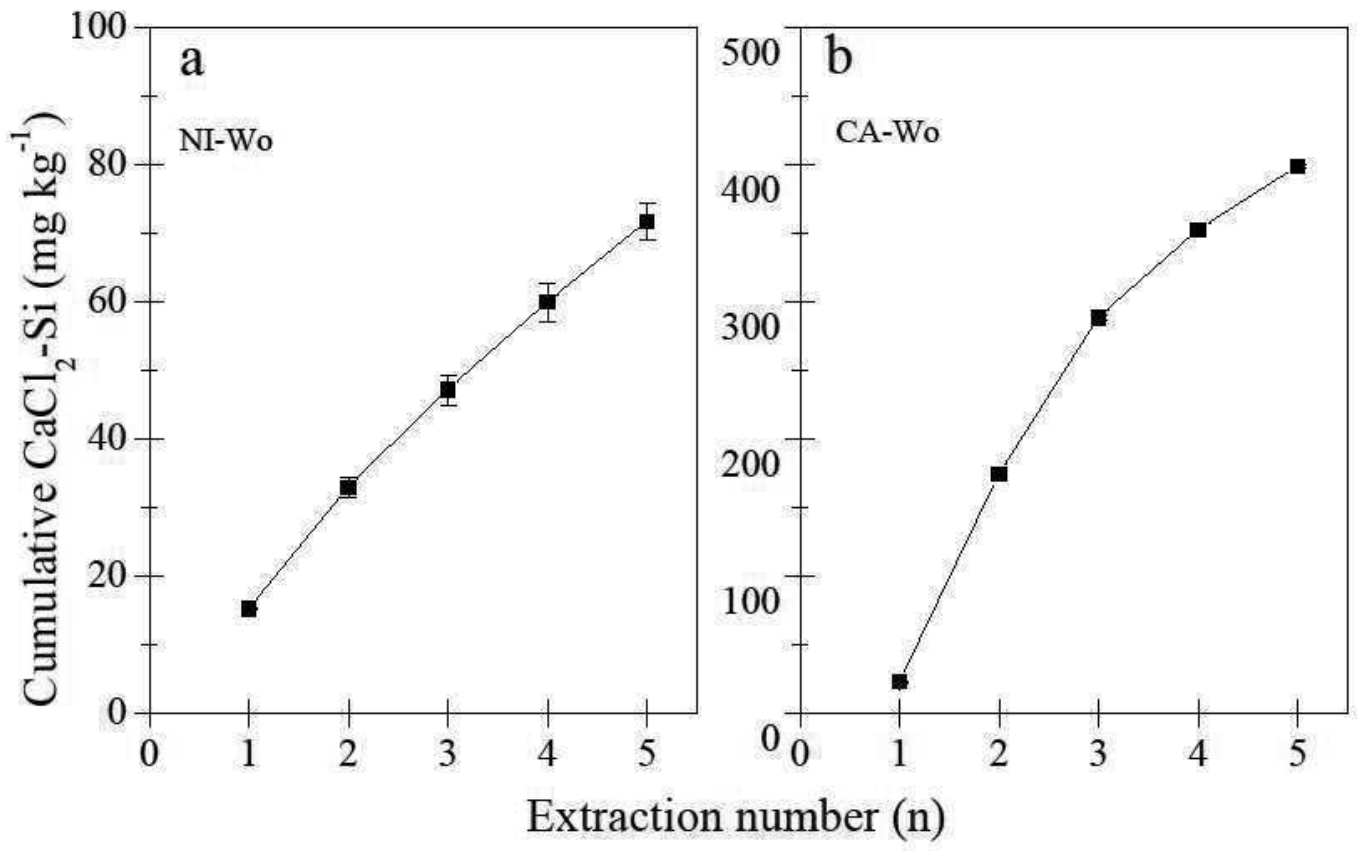

461
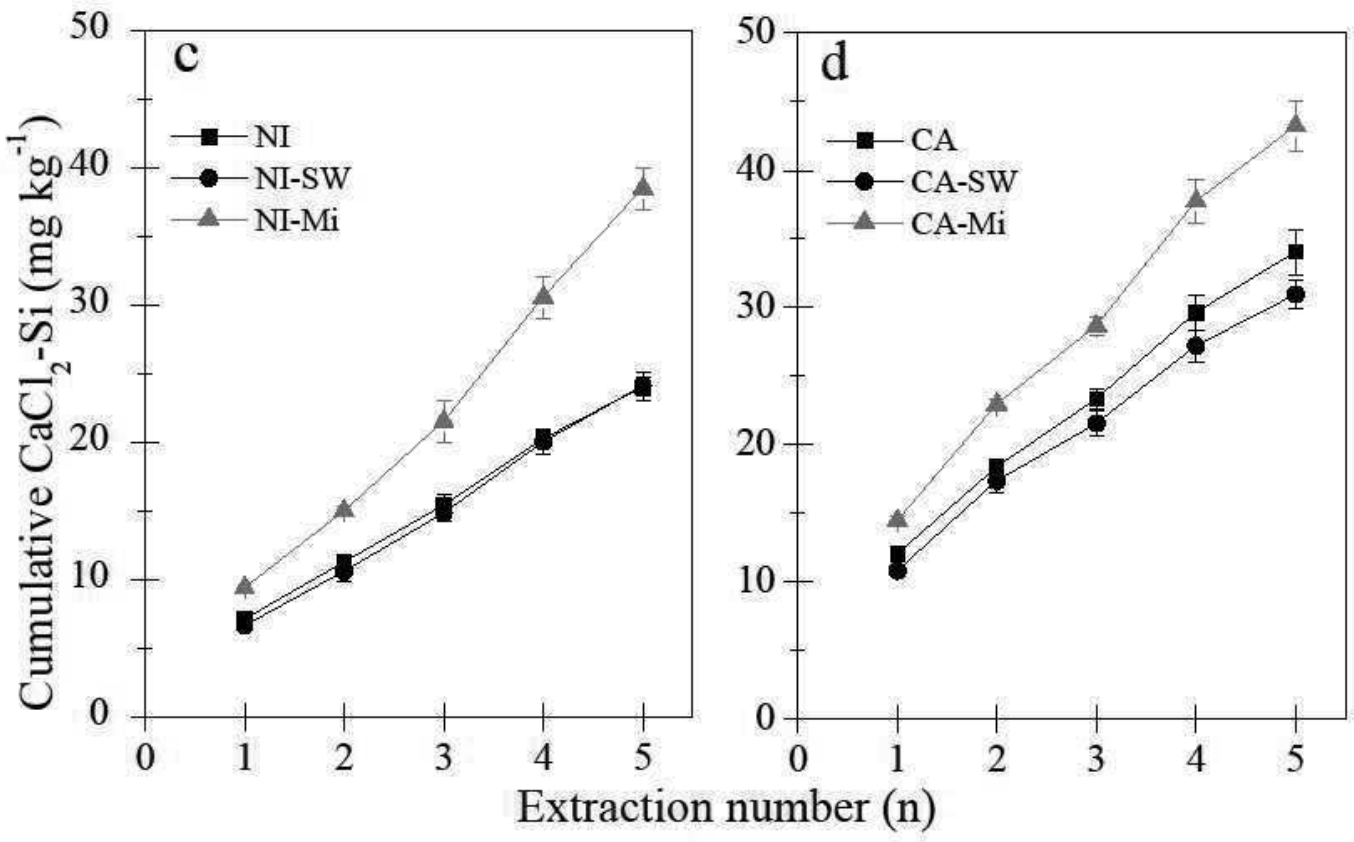

462

463

464

465

466

467
Figure 3. Plot of the cumulative amount of $\mathrm{CaCl}_{2}$ extractable Si content against the extraction number (the $\mathrm{Si}$ content at each number is added to the Si contents extracted following the preceding $(\mathrm{s})$ extraction(s) in ( $a, b)$ soil:wollastonite ( $a, b$ : NI-Wo and CA-Wo); (c) NI, NI-Mi and NI-SW, and (d) CA, CA-Mi and CA-SW. 


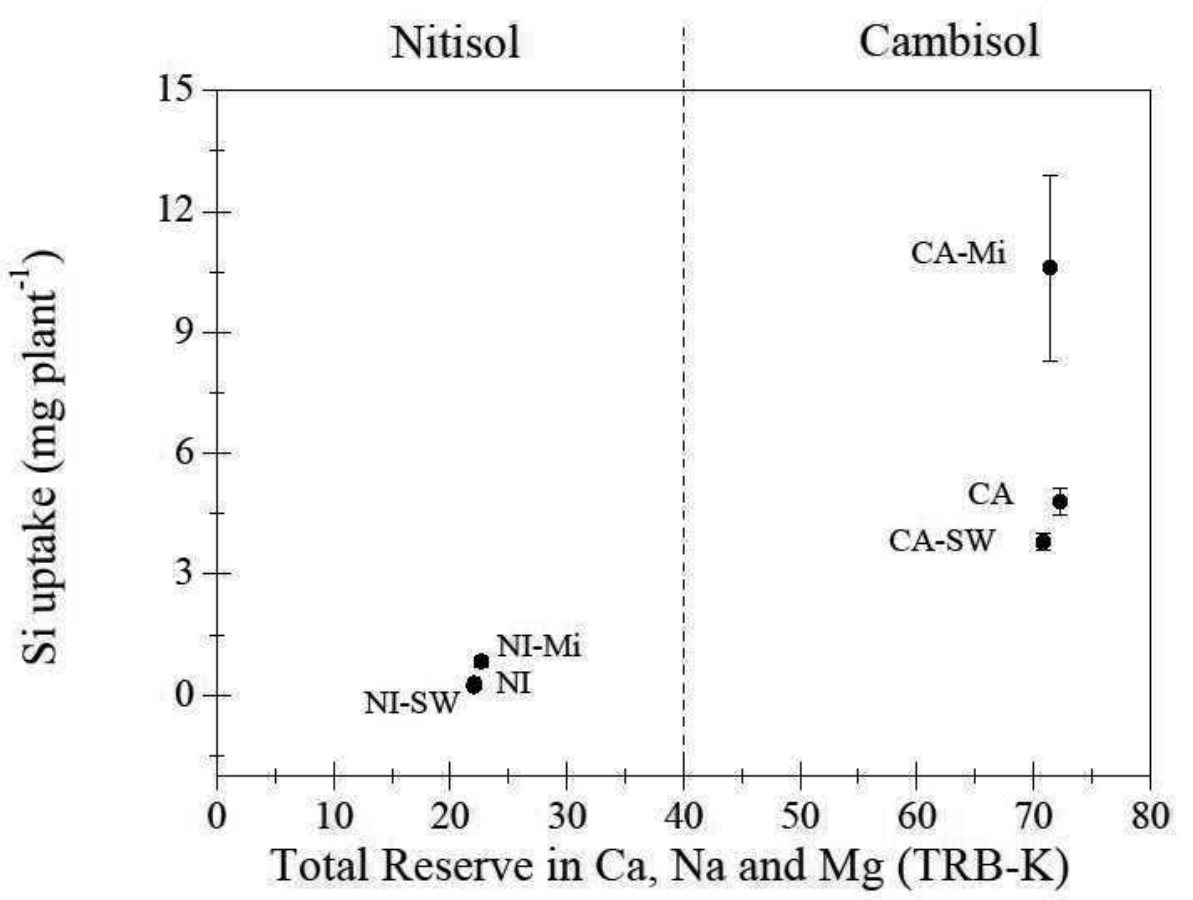

468

469 Figure 4. Plot of $\mathrm{Si}$ uptake by cotton plants against the total reserve of $\mathrm{Ca}, \mathrm{Mg}$ and $\mathrm{Na}$ minerals $470 \quad$ (excluding K-bearing muscovite) in the Cambisol (CA) and Nitisol (NI). 